\title{
Research on Collophane and Ions of Backwater in Yunnan
}

\author{
Ting $\mathrm{Hu}^{\mathrm{a}, *}$, Zhiyong $\mathrm{He}^{\mathrm{b}}$, Xiaofeng Yang ${ }^{\mathrm{c}}$ \\ Kunming Vocational and Technical College of Industry, Kunming, China \\ a378355587@qq.com, b123383244@qq.com, ' $44032652 @ q q . c o m$
}

Keywords: collophane; flotation; lons; backwater.

\begin{abstract}
For the problems of the collophane backwater in the production process, experimental study on the phosphate backwater in Yunnan has been carried. It examined the effect of main ions on the flotation backwater. It found that it will deteriorate collophane flotation index when the content of $\mathrm{Ca}^{2+}, \mathrm{Mg}^{2+}, \mathrm{SO}_{4}{ }^{2-}, \mathrm{PO}_{4}{ }^{3-}$ too high. In response to this phenomenon, it proposed the wastewater treatment process of phosphate beneficiation.
\end{abstract}

\section{Introduction}

Backwater using is an important link in the collophane flotation. Due to the complex properties and the extensive use of the flotation agents, this makes the complex composition and more toxic and harmful ingredients in the wastewater of phosphate beneficiation. If it directs emissions, not only pollute the environment, but also waste of water resources. But if it directly to recycling without treatment, it will worsen the sorting index by the organic and inorganic agents, suspended solids and inevitably ions, etc. present the waste water.

It shows that the ions which impact the positive flotation were mainly calcium ions, magnesium ions, phosphate ions and sulfate ions, followed by silicate ions and fatty acids ions. It will not be affected by calcium ions, magnesium ions and phosphate ions to anti-flotation. There are a lot of unavoidable ions in the pulp by the minerals dissolved in the process of the phosphate sorting. Some unavoidable ions adsorbed on mineral surfaces so that change the properties of the mineral surface. It reduces the floatability difference between the objective minerals and gangue minerals. It also can worsen the pulp environmental and consume large amounts of anionic collector, so that reduce flotation index.

\section{Run-of-mine ore properties}

We have researched on the run-of-mine ore. The analytic results of multi-element are shown in Table 1.

Table 1 Results of multi-element analysis

\begin{tabular}{ccccccc}
\hline Element & $\mathrm{P}_{2} \mathrm{O}_{5}$ & $\mathrm{MgO}$ & $\mathrm{CaO}$ & $\mathrm{SiO}_{2}$ & $\mathrm{Al}_{2} \mathrm{O}_{3}$ & $\mathrm{~F}$ \\
Content/\% & 21.98 & 1.54 & 32.75 & 31.34 & 1.61 & 1.04 \\
\hline Element & $\mathrm{Fe}_{2} \mathrm{O}_{3}$ & $\mathrm{CO}_{2}$ & A.I & Else & $\mathrm{K}_{2} \mathrm{O}$ & $\mathrm{Na}_{2} \mathrm{O}$ \\
Content/\% & 1.33 & 4.81 & 38.60 & 0.94 & 0.36 & 0.18 \\
\hline
\end{tabular}

The results of the multi-element analysis from table 1 show that the mainly useful minerals are collophane and the mainly gangue minerals are quartz, calcite and dolomite. This kind ore mainly present in irregular granular disseminated. It is cemented symbiosis between collophane and gangue minerals. 


\section{Beneficiation wastewater ions source}

It is generally been divided into kinds about the collophane beneficiation waste water. One is from concentration, which always been acidic. The other is the tailings waste water, which always close to neutral. The mainly ions which depress the phosphate direct flotation in the wastewater as follows: 1) $\mathrm{Ca}^{2+}$ and $\mathrm{Mg}^{2+}$. It mainly from the dissolution of dolomite and calcite minerals, the excess lime which treatment the wastewater, phosphate and carbonate which been decomposition by the addition of concentrated sulfuric acid in the reverse flotation processes. 2) $\mathrm{PO}_{4}{ }^{2-}$. It mainly comes from the industrial phosphoric acid. And a small amount are from the phosphate ore which been decomposition by the addition of concentrated sulfuric acid in the reverse flotation process. 3) $\mathrm{SO}_{4}{ }^{2-}$. It mainly comes from the addition of flotation reagents - sulfuric acid.

\section{Water treatment process}

After comparing a variety of methods, it determines using the process of "dual-alkali" + PAM coagulation treatment backwater. The test process shows in Figure 1.

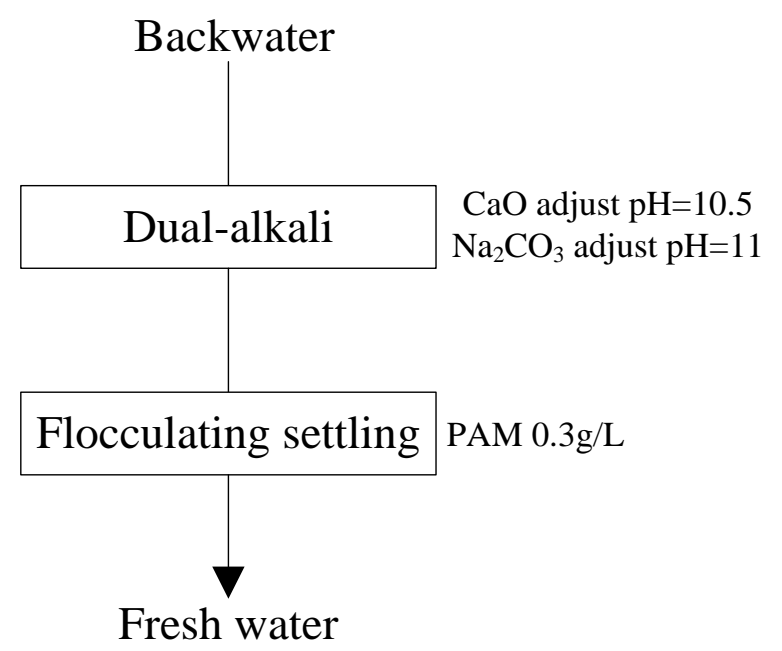

Fig 1 Flow sheet of the water treatment test

\section{Tailings backwater investigation}

Take flotation tailings water and mixing the treatment tailings backwater with fresh water to inspect contrast, the results show in Table 2. It shows that it is higher that the mixing tailings water and the tailings backwater than the fresh water about $\mathrm{Ca}^{2+}, \mathrm{Mg}^{2+}, \mathrm{PO}_{4}{ }^{3-}, \mathrm{SO}_{4}{ }^{2-}$ content. The content of $\mathrm{Ca}^{2+}$ and $\mathrm{Mg}^{2+}$ in the positive flotation backwater is too high. While calcium and magnesium ions can activate quartz and silicate gangue minerals, so that it will destroy the selective of fatty acids. Meanwhile, $\mathrm{Ca}^{2+}, \mathrm{Mg}^{2+}$ combined with the fatty acid anion, weaken the ability of the collector to the phosphate material. $\mathrm{PO}_{4}{ }^{3-}$ content too high will inhibit the flotation of phosphate material, and $\mathrm{SO}_{4}{ }^{2-}$ content too high will weaken the inhibition of water glass on the siliceous gangue. Therefore, it is the primary cause of the content of the $\mathrm{Ca}^{2+}, \mathrm{Mg}^{2+}, \mathrm{PO}_{4}{ }^{3-}$ and $\mathrm{SO}_{4}{ }^{2-}$ too high which impact the phosphate flotation.

Table 2 Results of backwater in tailings (mg/L)

\begin{tabular}{cccccc}
\hline Product & $\mathrm{pH}$ & {$\left[\mathrm{Ca}^{2+}\right]$} & {$\left[\mathrm{Mg}^{2+}\right]$} & {$\left[\mathrm{SO}_{4}{ }^{2-}\right]$} & {$\left[\mathrm{PO}_{4}{ }^{3-}\right]$} \\
\hline $\begin{array}{c}\text { Treatment } \\
\text { backwater }\end{array}$ & 9.53 & 68.33 & 19.18 & 1.87 & 1.74 \\
$\begin{array}{c}\text { Fresh water } \\
\text { Untreated }\end{array}$ & 7.45 & 84.57 & 53.64 & 197.83 & - \\
backwater & 7.11 & 579.37 & 129.77 & 1052.45 & 57.18 \\
\hline
\end{tabular}




\section{Dosage of lime milk test}

It removed the $\mathrm{SO}_{4}{ }^{2-}$ and $\mathrm{PO}_{4}{ }^{3-}$ ions using lime milk. Tailings backwater taken as test water, it adjusted to different $\mathrm{pH}$ value by adding different amounts of lime milk. And then examine the relationship between the tailings backwater $\mathrm{SO}_{4}{ }^{2-}$ and $\mathrm{PO}_{4}{ }^{3-}$ content and $\mathrm{pH}$ value. Results of the test show in Figure 2.

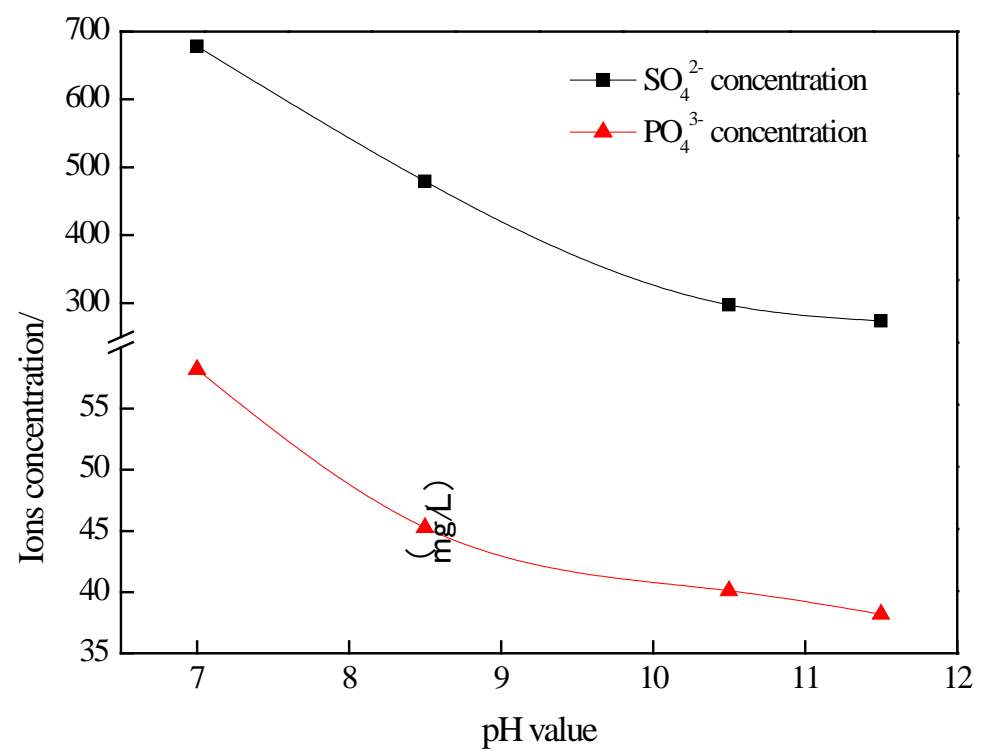

Fig 2 Results of lime milk dosage test

Results from Figure 2 show that the $\mathrm{SO}_{4}{ }^{2-}$ and $\mathrm{PO}_{4}{ }^{3-}$ concentration have a close relation with the amount of lime milk. With the increase of the amount of lime milk, the concentration of the $\mathrm{SO}_{4}{ }^{2-}$ and $\mathrm{PO}_{4}{ }^{3-}$ decreased. When the $\mathrm{pH}$ value reached $10.5, \mathrm{SO}_{4}{ }^{2-}$ and $\mathrm{PO}_{4}{ }^{3-}$ concentration decreased very little with continuing to add lime milk. Taking into account the amount of addition of lime milk and excessive lime slurry result in large $\mathrm{Ca}^{2+}$ concentration, test using lime milk adjusted to $\mathrm{pH} 10.5$.

\section{Dosage of $\mathrm{Na}_{2} \mathrm{CO}_{3}$ test}

Sodium carbonate can be precipitated calcium and magnesium ions in the pulp. Change the amount of sodium carbonate, to observe the test results. Results of the test show in Figure 3.

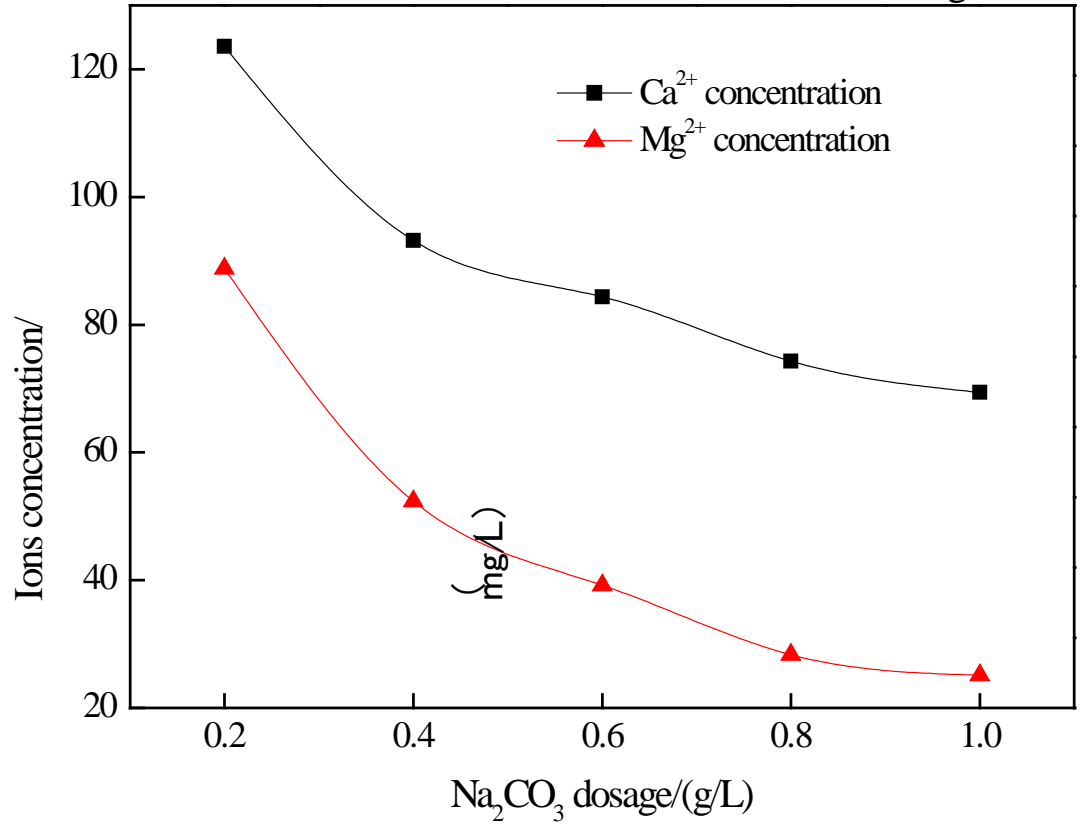

Fig 3 Results of Na2CO3 dosage test 
Results from figure 3 show that $\mathrm{Na}_{2} \mathrm{CO}_{3}$ can effectively remove calcium and magnesium ions in the backwater. With the dosage of sodium carbonate increasing, the amount of calcium and magnesium ions gradually decreased, while the dosage of sodium carbonate was $0.8 \mathrm{~g} / \mathrm{L}$, the amount of calcium and magnesium ions in the backwater was nearly with which in the clean water. So the dosage of sodium carbonate was $0.8 \mathrm{~g} / \mathrm{L}$.

\section{Conclusions}

1) Base on the properties of the run-of-mine ore, the mainly useful minerals are collophane and the mainly gangue minerals are quartz, calcite and dolomite. This kind ore mainly present in irregular granular disseminated. It is cemented symbiosis between collophane and gangue minerals.

2) After comparing a variety of methods, it determines using the process of "dual-alkali" + PAM coagulation treatment backwater.

3) Lime milk and sodium carbonate is used as removing sulphate ions, phosphate ions and calcium and magnesium ions, condition after the test, we adjusted the $\mathrm{pH}$ to 10.5 using lime milk and the dosage of sodium carbonate is $0.8 \mathrm{~g} / \mathrm{L}$.

\section{Acknowledgments}

The financial support from the scientific research fund project of Yunnan under the grant 2013 Y076 is gratefully acknowledged.

\section{References}

[1] H.H.Luo, Y.Q.Zuo, D.L.Li, Bench-scale Continuous Flotation Test of Yichang Phosphorite and Recycling of the Flotation Waste Water, J. Phosphate \& Compound Fertilizer,(2009.2) 87-89.

[2] H.H.Luo, D.L.Li, Y.L.Wang, Y.H.Wei, Research on Treatment Phosphorite Processing Wastewater with Double Alkali and Recycling Utilization, J. China Non-metallic Mining Industry Herald,(2008.3) p.48-50.

[3] Z.N.Bai, Z.X.Wang, Suggestion on the Use of Backwater in Phosphate Floatation, J. Yunnan Chemical Technology,(2009.2) p. 18-21. 